\title{
Spatial and temporal patterns of cattle feces deposition on rangeland
}

\author{
KENNETH W. TATE, EDWARD R. ATWILL, NEIL K. MCDOUGALD, AND MELVIN R. GEORGE
}

Authors are Rangeland Watershed Specialist, Agronomy and Range Science, University of California, Davis, Calif. 95616-8515; Environmental Animal Health Specialist, School of Veterinary Medicine, University of California, Veterinary Medicine Teaching and Research Center, Tulare, Calif. 93274; Natural Resources and Livestock Advisor, University of California Cooperative Extension, Madera, Calif. 93637; and Range and Pasture Specialist, Agronomy and Range Science, University of California, Davis, Calif. 95616-8515.

\begin{abstract}
The objective of this study was to identify and model environmental and management factors associated with cattle feces deposition patterns across annual rangeland watersheds in the Sierra Nevada foothills. Daily cattle fecal load accumulation rates were calculated from seasonal fecal loads measured biannually on $40 \mathrm{~m}^{2}$ permanent transects distributed across a 150.5 ha pasture in Madera County, Calif. during the 4 year period from 1995 through 1998. Associations between daily fecal load per season, livestock management, and environmental factors measured for each transect were determined using a linear mixed effects model. Cattle feces distribution patterns were significantly associated with location of livestock attractants, slope percentage, slope aspect, hydrologic position, and season. Transects located in livestock concentration areas experienced a significantly higher daily fecal load compared to transects outside of these concentration areas $(P<0.001)$. Percent slope was negatively associated with daily fecal load, but this association had a significant interaction with slope aspect $(P=\mathbf{0 . 0 2})$. Daily fecal load was significantly lower during the wet season compared to the dry season $(P=0.002)$. Daily fecal loading rates across hydrologic positions were dependent upon season. Our results illustrate the opportunities to reduce the risk of water quality contamination by strategic placement of cattle attractants, and provide a means to predict cattle feces deposition based upon inherent watershed characteristics and management factors.
\end{abstract}

Key Words: water quality, pathogens, grazing distribution, watershed management

Rangeland watersheds on the west slope of the Sierra Nevada Mountain Range serve as important source areas for California's drinking water supply, particularly the San Francisco Bay Area and the rapidly urbanizing Central Valley. These annual rangelands are grazed by cattle both year around and seasonally. Atwill (1996) reviews concerns raised by drinking water municipalities, public health officials, and regulatory agencies about the potential risk that pathogens (Cryptosporidium parvum and Giardia lamblia) contained in cattle feces on rangelands poses to drinking water supplies. Systematic assessment of the linkages between rangeland cattle production and transmission of water-borne

Research was funded in part by UC Division of Agriculture and Natural Resources 1995-96 Competitive Grants Program Grant \#020.

Manuscript accepted 16 Nov. 02.

\section{Resumen}

El objetivo de este estudio fue identificar y modelar los factores ambientales y de manejo asociados con los patrones de deposición heces fecales de bovinos a través de cunecas hidrológicas de pastizal anual en los pie de monte de la Sierra Nevada. Se calcularon las tasas diarias de la carga acumulativa de heces fecales de bovinos a partir de las cargas fecales estacionales medidas bianualmente en transectos permanentes de $\mathbf{4 0} \mathrm{m}^{2}$ distribuidos a través de un potrero de $\mathbf{1 5 0 . 5}$ ha en el condado de Madera, Calif., las mediciones se realizaron en un durante un periodo de 4 años, de 1995 a 1998 . Las asociaciones entre la carga fecal diaria por estación, el manejo del ganado y los factores ambientales medidos para cada transecto se determinaron usando un modelo lineal de efectos mixtos. Los patrones de distribución de la heces del ganado estuvieron significativamente asociados con la localización de atrayentes del ganado, el porcentaje de pendiente, el aspecto de la pendiente, la posición hidrológica y la época del año. Los transectos localizados en áreas de concentración de ganado experimentaron una carga diaria de heces fecales significativamente mayor que la de los transectos fuera de estas áreas de concentración $(P<0.001)$. El porcentaje de pendiente estuvo asociado negativamente con la carga diaria de heces, pero esta asociación tuvo una interacción significativa con el aspecto de la pendiente $(P=0.02)$. La carga diaria de heces fecales fue significativamente menor durante la época húmeda en comparación con la época seca $(P=0.002)$. La carga diaria de heces fecales fue significativamente menor durante la estación húmeda en comparación con la estación seca $(p=0.002)$. Las tasas de carga diaria fecal a través de las posiciones hidrológicas fueron dependientas de la época del año. Nuestros resultados ilustran las oportunidades para reducir el riesgo de contaminación de la calidad del agua mediante la ubicación estratégica de atrayentes del ganado y provee medios para predecir la deposición de heces fecales de ganado bovino basado en las características inherentes del a cuenca hidrológica $y$ factores de manejo.

pathogens to humans requires evaluation of the prevalence of pathogens in cattle herds (Atwill et al. 1999a), identification of associations between livestock management and pathogen prevalence (Atwill et al. 1999b), and investigation of the hydrologic transport of pathogens from cattle fecal deposits to water-bodies (Tate et al. 2000a, Atwill et al. 2002).

The spatial and temporal pattern of feces deposition by cattle grazing annual rangeland watersheds is also an important factor determining the risk rangeland beef cattle production poses to 
water quality. The timing of feces deposition relative to rainfall-runoff events, and the proximity of deposition to watershed areas contributing runoff, such as riparian areas, determine much of the potential for pathogens in fecal deposits to be transported to downstream water-bodies and potentially into drinking water supplies. Successful management of cattle feces distribution to reduce risk to water quality requires an understanding of the management and environmental factors determining the spatial distribution of livestock feces across annual rangeland watersheds during both wet (transport potential high) and dry (transport potential low) seasons. While there is significant information available about cattle grazing distribution and behavior on rangelands (Bailey et al. 1996), there is limited information available to quantitatively predict the temporal and spatial distribution of livestock feces on annual rangelands.

In general, cattle distribution patterns are variable and determined by the interactions of topography, water location, supplemental feed placement, forage abundance and quality, season, livestock species and class, and livestock cognitive abilities (Bailey et al. 1996). On annual rangeland in California, Wagnon (1968) concluded that cattle distribution, as measured by forage use, was determined by vegetation type, forage production, slope percentage, and season. The overall negative effect which increasing percent land slope has on cattle distribution and resultant forage utilization has long been established (Mueggler 1965, Cook 1966 , Ganskopp and Vavra 1987). Holechek et al. (1998) and Bailey et al. (1996) reach a general consensus that cattle use diminishes rapidly as site slope exceeds $10 \%$. Larsen (1996) concluded that cattle fecal distribution tends to be non-uniform and variable across a landscape, estimating that $0.4 \%$ to $2.0 \%$ of a pasture may be covered by fecal deposits. On rangeland in southeastern Utah, Buckhouse and Gifford (1976) reported $0.2 \%$ of the land surface covered with cattle fecal deposits at a stocking rate of 2 ha $\mathrm{AUM}^{-1}$.

The ability of managers to modify livestock distribution with practices such as water development, salt and feed placement has been well documented. Lange (1969) coined the term "piosphere" to describe the distinct trail, vegetation, and fecal load patterns radiating out from sheep watering troughs in South Australia. Miner et al. (1992) and Clawson (1993) found that the location of water troughs could be used to control cattle distribution and reduce time spent near riparian areas on eastern Oregon rangelands. Larsen (1989) reports cattle fecal loading as high as 7400 deposits $\mathrm{ha}^{-1}$ (4.5\% land surface coverage) below bedding trees in Oregon, and a loading of 6,067 deposits ha ${ }^{-1}$ near winter feeding areas. Bailey and Welling (1999) found that the density of cattle fecal pats was $560 \%$ greater in areas with supplemental feed $\left(3.3\right.$ pats $100 \mathrm{~m}^{-2}$ ) compared to areas without supplemental feed $\left(0.5\right.$ pats $\left.100 \mathrm{~m}^{-2}\right)$ on foothill rangeland in Montana. Bailey et al. (2001) illustrated the potential for managers to modify cattle distribution and forage utilization by strategic placement of supplemental feed in areas cattle would normally under-utilize. Harris et al. $(1998,2002)$ were able to manipulate traditional cattle travel patterns by placement of water and supplemental feed.

The first objective of this study was to identify the environmental and management factors determining spatial and temporal patterns of cattle fecal deposition across annual rangeland watersheds in California's Sierra Nevada foothills under ambient year-long cattle grazing. Our second objective was to develop a data-driven predictive model to estimate cattle fecal loading under specific environmental and management scenarios in this landscape.

\section{Methods}

\section{Study Site}

The study was conducted on a 150.5 ha pasture at the San Joaquin Experimental Range (SJER) located in the Sierra Nevada foothills in Madera County, Calif. $\left(37^{\circ} 6^{\prime} 8^{\prime \prime} \mathrm{N} 119^{\circ} 43^{\prime} 33^{\prime \prime} \mathrm{W}\right)$. Climate at SJER is Mediterranean with an average annual precipitation of $485 \mathrm{~mm}$ occurring almost entirely as rainfall November through May. Vegetation across the pasture is oak savannah with annual grassland understory. Blue oak (Quercus douglasii Hook \& Arn.) and interior live oak (Quercus wislizenii A.DC.) dominate the overstory, while annual grasses and forbs such as wild oats (Avena fatua L.), rip-gut brome (Bromus diandrus Roth), soft chess (Bromus mollis, L.), and redstem filaree (Erodium cicutarium (L.) L'Her) dominate the annual grassland understory.

The study pasture has a general aspect of north to northwest, with slopes ranging from 0 to $35 \%$. Elevation of the pasture ranges from $335 \mathrm{~m}$ to $457 \mathrm{~m}$. The pasture is drained by an intermittent creek that normally flows from January through March. Field surveys were conducted dur- ing storm events occurring January through April of 1995 to identify pasture areas which directly contribute surface runoff to the intermittent stream. The extent of this area varied through the wet season and during individual storms. This area of the pasture was termed the variable source area (VSA) following Hewlett and Hibbert (1967) and Bernier (1985). Based upon the field survey and topography, the VSA for the study pasture was defined as the area within $3 \mathrm{~m}$ of the thalwag of the intermittent stream draining the pasture and its ephemeral tributaries as well as the seasonal wetland swales throughout the pasture. Following this definition, the VSA represented 15.8 ha or approximately $10 \%$ of the total pasture area.

The 150.5 ha pasture was grazed continuously with a 16 to 24 head fall calving, cross-breed cow-calf herd throughout the study period (October 1995 through September 1999). The number of cows varied across years based upon seasonal and annual forage production dynamics. Annual stocking rates accounting for all herd animals for the 1995, 1996, 1997 and 1998 water year were $0.14,0.16,0.11$, and $0.13 \mathrm{AU} \mathrm{ha}^{-1} \mathrm{yr}^{-1}$, respectively.

\section{Study Design}

The study was a longitudinal survey of cattle fecal loading stratified across a set of management practices and environmental factors. In October 1995, 54 permanent $40 \mathrm{~m}^{2}$ (30.5 m long by $1.3 \mathrm{~m}$ wide) belt transects were established across the study pasture. In October 1997, an additional 20 transects were established to increase the sample size to 74 transects. Transects were established across the pasture in a stratified random design. Transects were established perpendicular to slope contour. Stratifications were hydrologic position (ridge, hillslope, or VSA) and livestock concentration area (yes or no). Ridge (1995-96 $n=4$; 1997-98 $n=6)$, hillslope (1995-96 n = 29; 1997-98 $n=42)$, and VSA transects $(1995-96 n=16 ; 1997-98$ $\mathrm{n}=18$ ) were randomly placed within each hydrologic position. Lastly, livestock concentration area transects (1995-96 $\mathrm{n}=5$; $1997-98 n=8$ ) were established within 30 $\mathrm{m}$ of all stock water troughs (2) and supplemental feed and salt sites (3) within the pasture. Slope (\%), aspect (north, south), hydrologic position (hillslope, ridge, VSA), surface rock cover (\%), oak overstory canopy cover $(\%)$, cattle trail through transect (yes, no), and vertical and horizontal distance $(\mathrm{m})$ to nearest livestock concentration site were measured for each transect. 


\section{Daily Fecal Load Accumulation \\ Rate}

Daily cattle fecal load accumulation rate on a dry weight basis $\left(\mathrm{kg} \mathrm{ha}^{-1} \mathrm{day}^{-1}\right)$ was measured in each transect for the wet (1Oct through 30-Apr) and dry (1-May through 30-Sep) season of the 1995-96, 1996-97, 1997-98, and 1998-99 water years (1-Oct through $30-\mathrm{Sep}$ ). Four years of data were collected for 54 transects (established October 1995), and 2 years for 74 transects (additional 20 established October 1997).

On about 1-Oct and about 1-May of each water year, dry weight fecal load $\left(\mathrm{kg} \mathrm{ha}^{-1}\right)$ in each transect was measured and all fecal material was cleared from the transect, allowing determination of wet and dry season fecal material accumulation. Dry weight fecal load $\left(\mathrm{kg} \mathrm{ha}^{-1}\right)$ in each transect was measured using the comparative fecal load methodology (Tate et al. 2000b). This methodology is an ocular estimation technique where the dry weight of each individual fecal pat in the transect is estimated and the fecal load of the transect is calculated as the sum of individual fecal pat dry weights in the transect. Daily fecal load accumulation rate on a dry weight basis (DFLAR) $\left(\mathrm{kg} \mathrm{ha}^{-1}\right.$ day $\left.^{-1}\right)$ was then calculated for each plot for each of the 2 seasons for each of the 4 years by dividing the fecal load per sample period by the number of days in that sample period.

\section{Statistical Analysis and Model Development}

The basic data structure was a biannual repeated measure of cattle feces accumulation across 54 transects for 4 years and an additional 20 transects for 2 years, resulting in 511 complete data records. The association between the daily fecal load accumulation rate per season (wet, dry) and the various transect management and environmental factors was determined using a linear mixed effects model (Pinheiro and Bates 2000). Examination of residual errors demonstrated marked heteroscedasticity within the daily fecal load accumulation rate data which was overcome by a square root transformation of this data in conjunction with the use of an exponential variance function (Pinheiro and Bates 2000).

In the linear mixed effects analysis, management and environmental factors were modeled as fixed effects; transect was modeled as a random or group effect (74 unique transects read either 4 to 8 times); and the outcome variable was the square root of the daily fecal load accumulation rate $\left(\mathrm{DFLAR}^{0.5}\right)$ for each transect.
Each management and environmental factor and all 2-way interactions were offered to the model in a forward stepping algorithm with a P-value of $\leq 0.10$ required for entry into the final model. Final model coefficients were estimated using restricted maximum likelihood, and P-values for each coefficient was estimated using the Wald statistic (Pinheiro and Bates 2000).

\section{Results}

\section{Linear Mixed-Effects Model}

After controlling for substantial group or random effects, in part a result of repeated measures on each transect, a variety of management and environmental factors were determined to be significantly ( $\mathrm{P}$ $<0.1$ ) associated with daily fecal load accumulation rate (Table 1). The overall fit of the model predicting the square root of daily fecal load accumulation rate $\left(\mathrm{DFLAR}^{0.5}\right)$ is illustrated by the agreement between the observed values and those predicted by the linear mixed effects model (Fig. 1).

Table 1. Linear mixed-effects model predicting square root of daily fecal load accumulation rate $\left(\right.$ DFLAR $\left.^{0.5}\right)\left(\mathrm{kg} \mathrm{ha}^{-1}\right.$ day $\left.^{-1}\right)$ by cattle grazing annual rangeland at San Joaquin Experimental Range, 1995-98. Coefficients quantify the expected effect of each factor on DFLAR ${ }^{0.5}$. For the categorical factors (year, concentration site, aspect, season, and hydrological position) the coefficient represents the expected effect of each factor level relative to the reference level. The coefficient for slope represents the incremental change in DFLAR $^{0.5}$ per incremental change in percent slope.

\begin{tabular}{|c|c|c|c|}
\hline Model Term & Coefficient & $95 \% \mathrm{CI}^{2}$ & P-value \\
\hline Intercept & 0.48 & $0.41,0.55$ & 0.0001 \\
\hline \multicolumn{4}{|l|}{ Year } \\
\hline 19951 & 0.0 & - & - \\
\hline 1996 & 0.02 & $-0.003,0.040$ & 0.08 \\
\hline 1997 & -0.03 & $-0.04,-0.02$ & 0.0001 \\
\hline 1998 & -0.01 & $-0.020,-0.003$ & 0.008 \\
\hline \multicolumn{4}{|l|}{ Concentration Site } \\
\hline Yes $^{1}$ & 0.0 & - $\quad$ & - \\
\hline No & -0.14 & $-0.20,-0.07$ & 0.0001 \\
\hline Slope & -0.007 & $-0.010,-0.004$ & 0.0002 \\
\hline \multicolumn{4}{|l|}{ Aspect } \\
\hline North $^{1}$ & 0.0 & - & - \\
\hline South & -0.01 & $-0.05,-0.01$ & 0.65 \\
\hline \multicolumn{4}{|l|}{ Season } \\
\hline Dry $^{1}$ & 0.0 & - & - \\
\hline Wet & -0.04 & $-0.06,-0.02$ & 0.002 \\
\hline \multicolumn{4}{|c|}{ Hydrologic Position } \\
\hline Ridge $^{1}$ & 0.0 & - & - \\
\hline Hillslope & -0.06 & $-0.10,-0.01$ & 0.02 \\
\hline $\mathrm{VSA}^{2}$ & -0.03 & $-0.050,0.001$ & 0.06 \\
\hline \multicolumn{4}{|l|}{ Slope x Aspect } \\
\hline Slope-North ${ }^{1}$ & 0.0 & - & - \\
\hline Slope-South & 0.003 & $0.0003,0.006$ & 0.03 \\
\hline \multicolumn{4}{|c|}{ Season x Hydrologic Position } \\
\hline Wet-Ridge ${ }^{1}$ & 0.0 & - & - \\
\hline Wet-Hillslope & 0.03 & $-0.008,0.06$ & 0.13 \\
\hline Wet-VSA & -0.01 & $-0.03,0.001$ & 0.06 \\
\hline
\end{tabular}

${ }_{1}^{1}$ Reference category for each categorical variable.

${ }^{2} 95 \%$ confidence interval for coefficient (lower, upper).

${ }^{3}$ Variable source area. expected effect of each factor on DFLAR $^{0.5}$. For the categorical factors in the model (year, concentration site, aspect, season, and hydrological position) the coefficient represents the expected effect of each level (e.g. 1996, 1997, 1998 for year) of the factor relative to the reference level (e.g. 1995 for year) for the factor. For slope, the only continuous factor in the model, the coefficient represents the incremental change in DFLAR ${ }^{0.5}$ per incremental change in percent slope. Surface rock cover (\%), oak overstory canopy (\%), vertical and horizontal (m) distance to nearest livestock concentration site, and daily fecal load accumulation rate (P > 0.10 ).

\section{Management Factors}

Transects located in livestock concentration areas experienced a significantly higher $\operatorname{DFLAR}^{0.5}\left(0.14 \mathrm{~kg} \mathrm{ha}^{-1}\right.$ day $\left.^{-1}\right)$ compared to transects outside of these concentration areas $(\mathrm{P}<0.001)$ (Table 1). There was a significant year effect such that
The coefficients in Table 1 quantify the presence of a cattle trail in the transect were not significantly associated with 


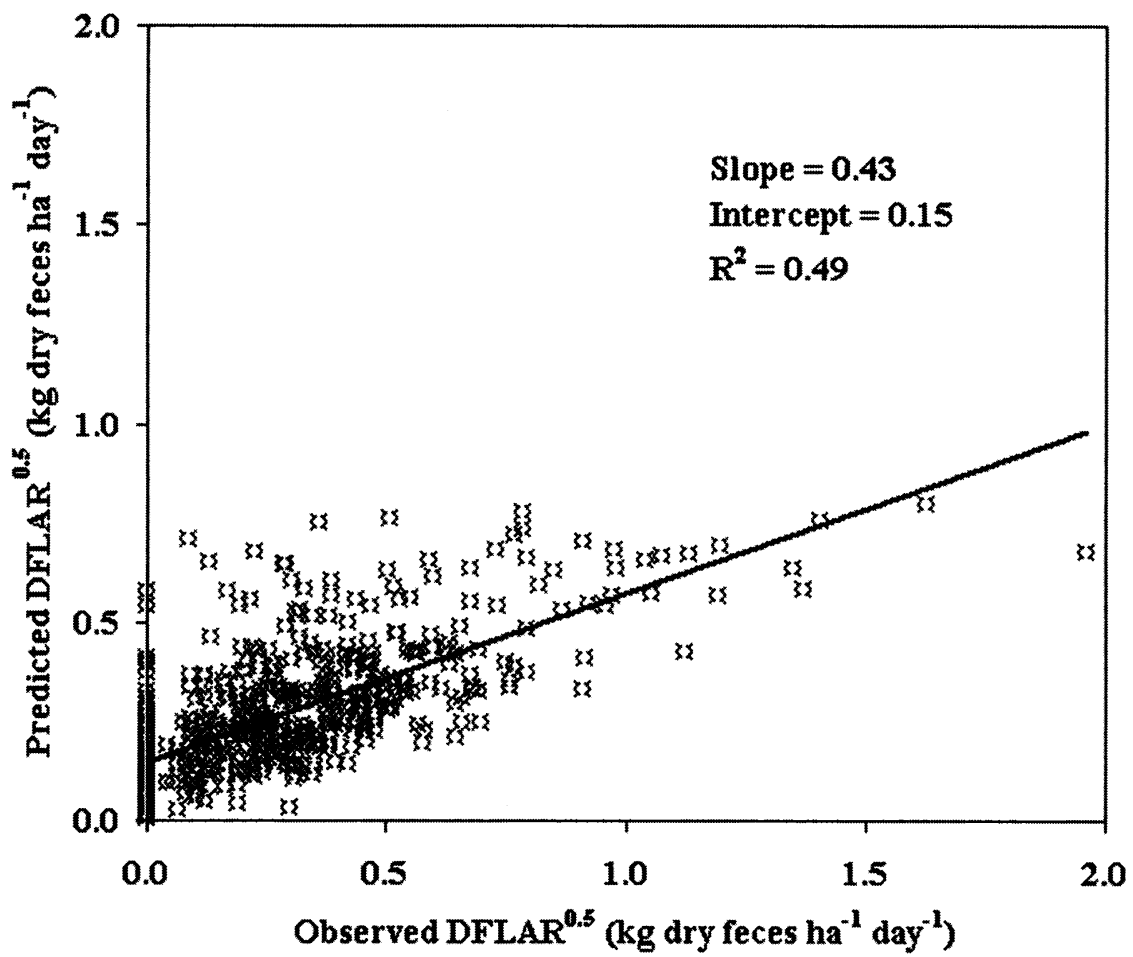

Fig. 1. Square root of observed daily cattle fecal load accumulation rate (DFLAR ${ }^{0.5}$ ) versus DFLAR $^{0.5}$ predicted by a linear mixed effects model containing year $(1995,1996,1997$, 1998), livestock concentration site (Yes, No), slope (\%), aspect (north, south), season (wet, dry), hydrologic position (ridge, hillslope, variable source area), a slope by aspect interaction, and a season by hydrologic position interaction.
Daily fecal load accumulation rate was significantly lower during the wet season compared to the dry season $(\mathrm{P}=0.002$, Table 1, Fig. 3 and 4). Hydrologic position within the watershed was associated with the rate of fecal accumulation, such that ridges accumulated more fecal material than hillslopes and the variable source area (Fig. 4). The association between hydrological position and cattle fecal material deposition was in part influenced by the prevailing season, in that there was a significant interaction term between season and hydrologic position $(\mathrm{P}<0.001)$. Relative to ridges and the variable source area (VSA), hillslopes experienced the least reduction in fecal accumulation during the wet season compared to the dry season (Fig. 4).

\section{Discussion}

These results indicate that a complex and interacting set of management and environmental factors must be considered when measuring, predicting, or managing feces loading by cattle across annual rangeland watersheds. The data-driven statistical model reported in Table 1 explicitly predicts the spatial-temporal distribu- daily fecal load accumulation rate was lower during 1997 and 1998 compared to 1995, while 1996 was higher than 1995 (Table 1, Fig. 2). The significance of year in the model may indicate the sensitivity of this fecal loading estimation method to changes in stocking rate.

\section{Environmental Factors}

Percent slope of the transect was negatively associated with daily fecal load accumulation rate, but this association had a significant interaction with aspect $(\mathrm{P}=$ 0.02 ) such that for every $10 \%$ increase in slope, DFLAR ${ }^{0.5}$ decreased by $0.07 \mathrm{~kg} \mathrm{ha}^{-1}$ day $^{-1}$ for north facing slopes yet decreased by only $0.04 \mathrm{~kg} \mathrm{ha}^{-1}$ day $^{-1}$ for south facing slopes (Fig. 3). South-facing slopes tended to accumulate more cattle fecal material relative to equivalently sloped north-facing slopes. The difference between the cattle fecal loading rates for north-facing as compared to south-facing slopes becomes negligible as percent slope approaches 0 (Fig. 3), indicating that the effect of aspect on DFLAR ${ }^{0.5}$ is most pronounced at steeper slopes. This point is corroborated by the lack of significance for the main term of aspect $(P=0.65)$ (Table 1).

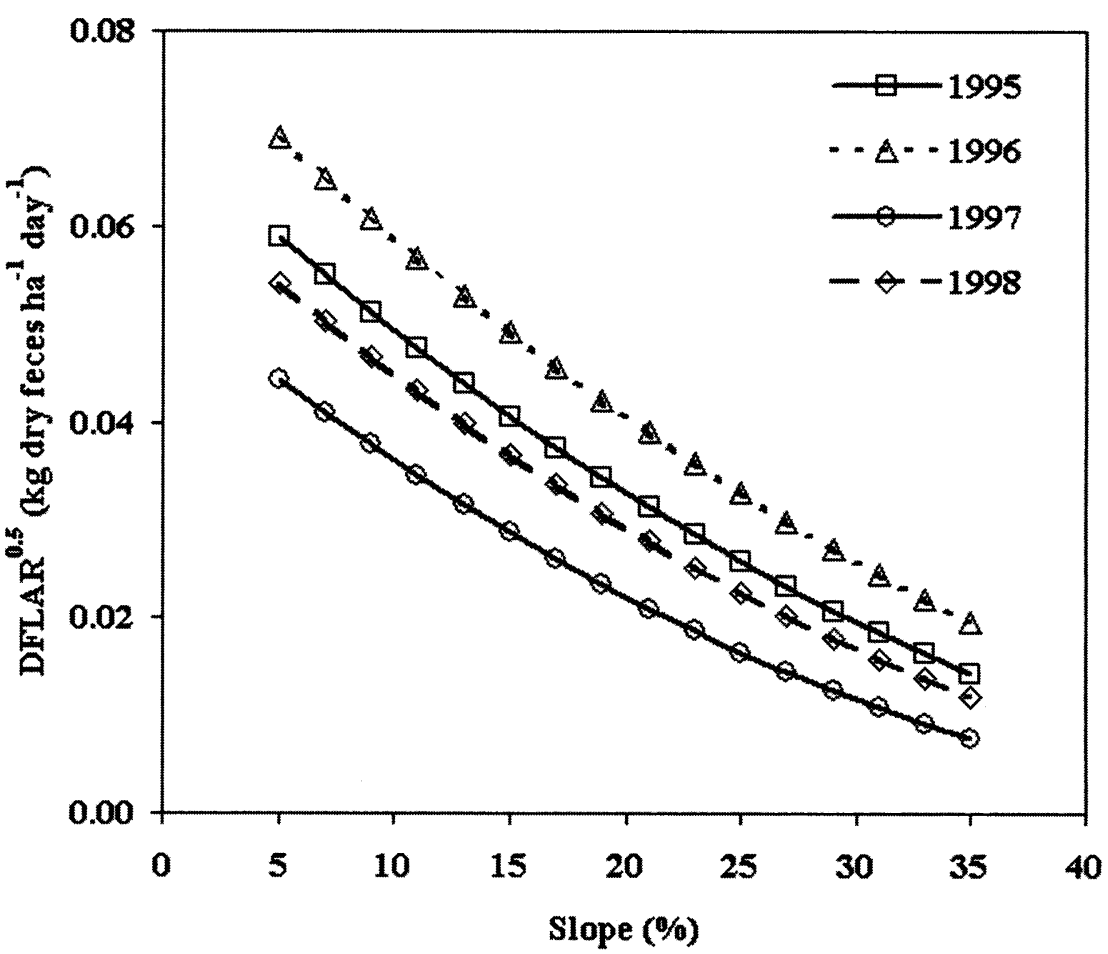

Fig. 2. Predicted square root of daily fecal load accumulation rate $\left(\operatorname{DFLAR}^{0.5}\right)$ for each study year as a function of slope $(\%)$. 


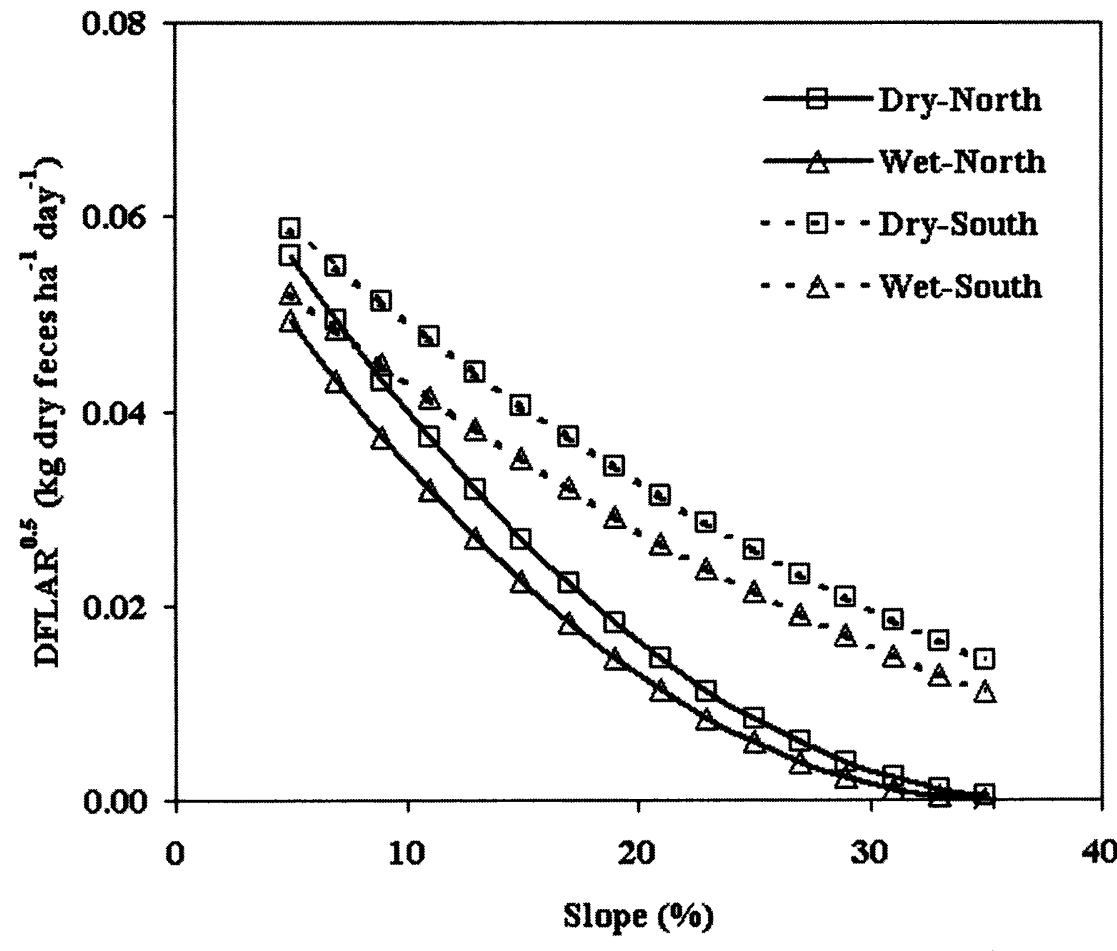

Fig. 3. Predicted square root of daily cattle fecal load accumulation rate (DFLAR ${ }^{0.5}$ ) as a function of season (wet, dry), aspect (north, south), and slope (\%). Units for DFLAR ${ }^{0.5}$ are kg dry feces ha' ${ }^{-1}$ day $^{-1}$. have reported substantially higher cattle fecal loading near supplemental sites and bedding areas (Larsen 1996, Bailey and Welling 1999). Our results correlate well with research illustrating the potential to modify cattle distribution and forage utilization by strategic placement of supplemental feed (Bailey et al. 2001, Harris et al. 1998, 2002). Managers should place cattle attractants in watershed and pasture areas which have limited surface runoff connection to streams or other water-bodies.

Ridges and hillslopes are the most hydrologically remote areas, while the variable source areas (VSA) are the most hydrologically connected areas on rangeland watersheds in the south Sierra Nevada foothills. Cattle fecal loading rate across these landscape positions is dependent upon season (Fig. 4). Fecal loading rate was significantly greater in the VSA during the dry season compared to the wet season. However, loading rates in the VSA declined dramatically, to levels equal to hillslope positions, during the wet season. The affinity of livestock for VSAs during the dry season can be attributed to the presence of green feed and water during the first half of the season (May-July) according to work on the San Joaquin tion of daily fecal material accumulation rate across an annual rangeland watershed. Fecal loading patterns likely do not correlate perfectly with variables used to describe grazing distribution (forage utilization patterns) or livestock behavior (time spent foraging, loafing, traveling). While there is certainly overlap in the factors determining livestock grazing behavior and fecal loading on a given landscape, there are also factors unique to each of these components of livestock grazing. Ideally, a single robust model predicting both livestock activity (grazing distribution and behavior) and resultant environmental impacts (fecal loading, forage utilization, riparian area damage) will be developed.

Our work shows that water troughs and supplemental feed significantly increase daily fecal accumulation rate at, and near, sites where these attractants are located. This result illustrates the potential for management to increase or decrease risk of manure-borne contaminants to water quality based upon the location of livestock attractants within a watershed or riparian pasture. Placement of a cattle attractant near a stream will increase daily fecal loading rate and risk to water quality, while strategic placement away from the stream can decrease fecal loading and associate risks near the stream. Previous studies

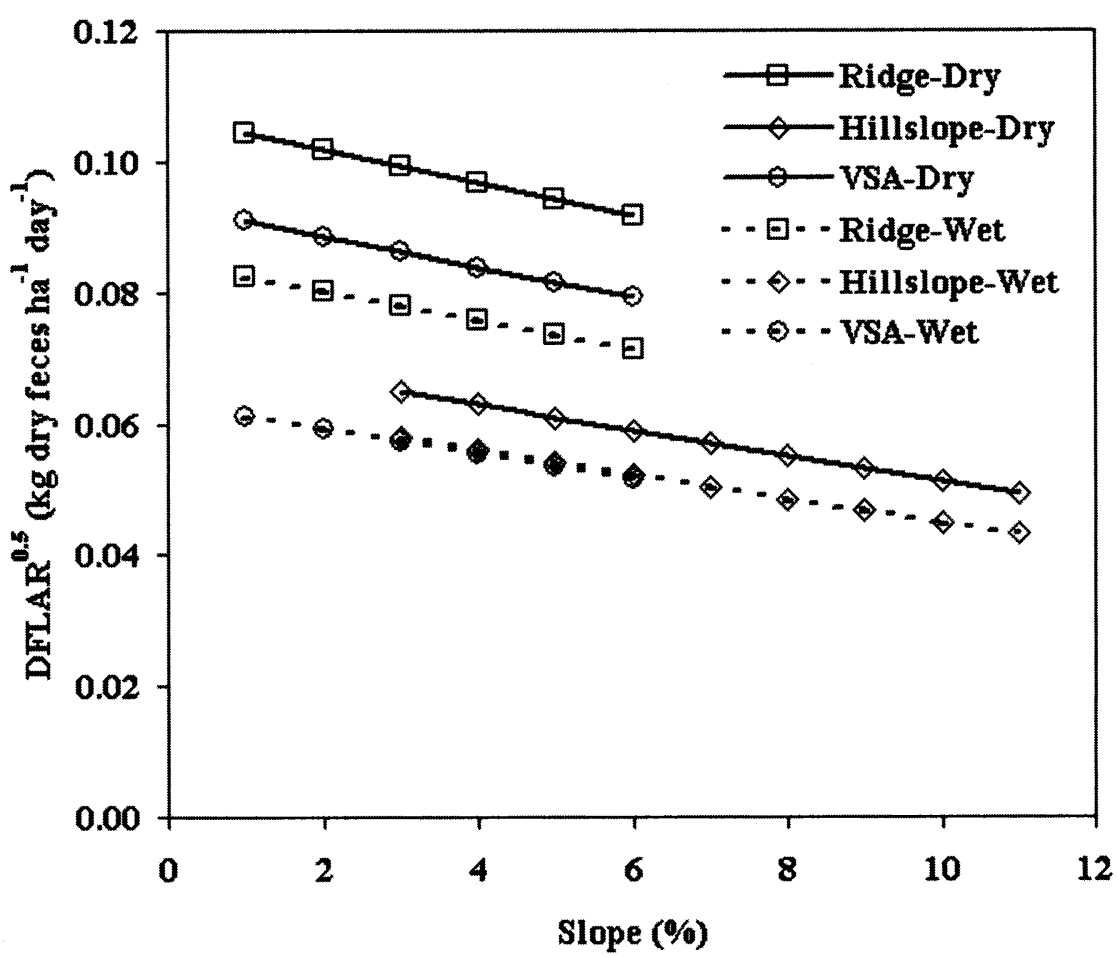

Fig. 4. Predicted square root of daily cattle fecal load accumulation rate (DFLAR ${ }^{0.5}$ ) as a function of season (wet, dry), hydrologic position (ridge, hillslope, variable source area (VSA)), and slope (\%). 
Experimental Range (SJER) by Wagnon (1968). During the wet season, green feed and surface water (pools and puddles) are uniformly available across these watersheds providing cattle little incentive to selectively utilize swales and other riparian areas. Harris et al. (1998) found similar seasonal trends in the spatial distributional patterns of livestock on the SJER.

Regardless of season, ridge positions were associated with higher fecal loading rates than either hillslope or VSA positions. Based upon 3 years of observations of beef cattle activity across 4 pastures, Wagnon (1963) reported that beef cattle at the SJER spent 58 to $85 \%$ of their annual feeding time on open slopes and 22 to $25 \%$ on swales. Wagnon (1963) does not differentiate cattle feeding time spent on hillslope $v$. ridge positions. Ridges at SJER are characterized by open canopy conditions and slopes less than $<5 \%$ while hillslopes are characterized by slopes ranging from 5 to $35 \%$ with variable brush, canopy and rock cover (Wagnon 1968). The higher fecal loading rate on ridges might be explained by the affinity of cattle for ridge positions relative to hillslopes because of the low slope, open conditions, and favorable microclimate of this landscape position. The apparent preferential deposition of fecal material by cattle on ridges is an association upon which managers can capitalize upon by strategic placement of cattle attractants in these hydrologically remote areas.

As land slope in the study pasture increased to $35 \%$, fecal loading by cattle was significantly reduced. Fecal loading rate decreased 50 to $99 \%$ at locations with a 20 to $30 \%$ slope compared to sites with a 1 to $5 \%$ slope. In a theoretical landscape grazing distribution model, Bailey et al. (1996) discuss the use of slope as an abiotic factor constraining site forage value as slope increases. While slope is clearly a factor determining cattle distribution across rangeland landscapes, both Mueggler (1965) and Cook (1966) clearly illustrate that the effect of slope on cattle use of an area is not a simple relationship. Cook (1966) found significant interactions between slope (\%) and other variables (distance to water, \% maximum slope between site and water, etc.) when attempting to predict site use by cattle on mountain range in northern Utah.

We found that slope and aspect (north, south) interacted to determine fecal loading rates. We observed preferential deposition of fecal material by cattle along steeper slopes facing south compared to steeper slopes facing north. However, the magnitude of the effect of aspect on fecal loading rate diminished substantially as slope approaches zero (Fig. 3). In this landscape, aspect can account for differences in microclimate, as well as in the occurrence, amount and composition of forage production. Combinations of favorable forage and microclimate create conditions preferred by the cattle at higher slopes with a southerly aspect compared to a northerly aspect.

We found significantly lower daily fecal loading rates (on a dry weight basis) during the wet season compared to the dry season. Forage quality, digestibility, and moisture content is higher on annual rangeland during the winter growing season compared to the summer dormant season. George et al. (1984) defined the annual forage production curve for SJER. While the growing season can last from October through April, the bulk of forage production occurs from roughly March through April. The period October through February is often characterized as "the inadequate green season", when forage growth is limited due to cold temperatures. Forage during the period May through September is composed of the dry residual forage produced during the period October through April, with some green forage remaining in the swales until mid June.

The reduced daily fecal loading rate (on a dry weight basis) observed in this study during October through April relative to the May through September dry season may be a result of several factors: 1 . Inadequate feed availability during the period October through February; 2 . Greater forage use efficiency resulting in less available preferred forage creating less fecal output; and 3. More rapid erosion and decay of deposited feces. Without direct measurements of forage amount, quality, intake, fecal output, and feces decay across the wet season it is difficult to determine which factors contributed to the lower daily fecal loading rates observed in this study. For future work, we recommend that timing of fecal load measurements be matched to identifiable changes in forage production and quality. On annual rangeland we recommend sampling to capture the October through February inadequate green season, March through April to capture the rapid spring growth season, May through June to capture the period when green forage remains in swales while upland forage is dry, and July through September when forage is dry throughout the landscape.

\section{Conclusions}

Spatial and temporal patterns of cattle fecal deposition across oak savannah watersheds in California's southern Sierra Nevada foothills is dependent upon a complex and interacting group of management and environmental factors. We were able to successfully identify and model the effect of many of these variables. However, information on seasonal forage production, forage quality, and microclimate across the landscape is required to fully interpret spatial and temporal fecal loading associations identified in our study. Factors we found to affect cattle feces distribution included location of livestock attractants, slope, aspect, topographic position, and season. Our results illustrate some of the opportunities available to grazing managers on these rangelands to reduce the risk to water quality from cattle feces by strategic placement of supplemental feed grounds and stock water troughs. Our results also provide a means to predict cattle feces deposition, allowing identification and prioritization of risk to water-bodies across this landscape based upon both inherent watershed characteristics and management factors on this range type.

For future studies, it would be beneficial to integrate the examination of livestock distribution, behavior, resultant environmental impacts, microclimate, forage, and topographic factors simultaneously across a single landscape. Numerous efforts have been, and continue to be, conducted where only livestock distribution and behavior, or only livestock environmental impacts are measured. A comprehensive approach across several range types is required before livestock distribution - behavior management - inherent site characteristics - environmental impacts can be understood and predicted at multiple spatial and temporal scales.

\section{Literature Cited}

Atwill, E.R. 1996. Assessing the link between rangeland cattle and water-borne Cryptosporidium parvum infection in humans. Rangelands. 18:48-51.

Atwill, E.R., E.M. Johnson, and M.C. Pereira. 1999b. Association of herd composition, stocking rate, and duration of calving season with fecal shedding of Cryptosporidium parvum oocysts in beef herds. J. Amer. Veterinary Med. Assoc. 215:1833-1838 
Atwill, E.R., L. Hou, B.M. Karle, T. Harter, K.W. Tate, and R.A. Dahlgren. 2002. Transport of Cryptosporidium parvum oocysts through vegetated buffer strips and estimated filtration efficiency. Applied and Environ. Microbiology. 68: In Press Nov 02 Issue, page numbers forth-coming.

Atwill, E.R., E.M. Johnson, D.J. Klingborg, G.M. Veserat, G. Markegard, W.A. Jensen, D.W. Pratt, R.E. Delmas, H.A. George, L.C. Forero, R.L. Phillips, S.J. Barry, N.K. McDougald, R.R. Gildersleeve, and W.E. Frost. 1999a. Age, geographic, and temporal distribution of fecal shedding of Cryptosporidium parvum oocysts in cow-calf herds. Amer. J. Vet. Res.. 60:420-425.

Bailey, D.W. and G. R. Welling. 1999. Modification of cattle grazing distribution with dehydrated molasses supplement. J. Range Manage. 52:575-582.

Bailey, D.W., G.R. Welling, and E.T. Miller. 2001. Cattle use of foothills rangeland near dehydrated molasses supplement. J. Range Manage. 54:338-347.

Bailey, D.W., J.E. Gross, E.A. Laca, L.R. Rittenhouse, M.B. Coughenhour, D.M. Swift, and P.L. Simms. 1996. Mechanisms that result in large herbivore grazing distribution patterns. J. Range Manage. 49:386-400.

Bernier, P.Y. 1985. Variable source areas and storm-flow generation: an update on the concept and a simulation effort. J. Hydrology. 79:195-213.

Buckhouse, J.C. and G.F. Gifford. 1976. Water quality implications of cattle grazing on a semi-arid watershed in southeastern Utah. J. Range Manage. 29:109-113.
Clawson, J.E. 1993. The use of off-stream water developments and various water gap configurations to modify the watering behavior of grazing cattle. M.S. Thesis. Oregon State Univer. Corvallis, Ore.

Cook, C.W. 1966. Factors affecting utilization of mountain slopes by cattle. J. Range Manage. 19:200-204.

Ganskopp, D. and M. Vavra. 1987. Slope use by cattle, feral horses, deer, and bighorn sheep. Northw. Sci. 61:74-81.

George, M.R., J.W. Menke, and J. Bartolome. 1984. Annual grassland forage productivity. University of California Division of Agriculture and Natural Resources Leaflet 21378. 4p.

Harris, N.R., M.R. George, D.E. Johnson, and N.K. McDougald. 1998. Supplement induced changes of cattle distribution on California foothill rangeland, p. 217. In: Proc. Amer. Water Resources Assoc. and Soc. for Range Manage. Speciality Conference on Rangeland Manage. and Water Resources. Reno, Nev.

Harris, N.R., D.E. Johnson, M.R. George, and N.K. McDougald. 2002. The effect of topography, vegetation, and weather on cattle distribution at the San Joaquin Experimental Range, California, p. 53-64. In: R.B. Standiford, D. McCreary, and K.L. Purcell (eds) Proc. $5^{\text {th }}$ Symp. on Oak Woodlands. San Diego, Calif. Oct. 22-25, 2001. USDAFS Gen. Tech. Rep. PSW-GTR-184.

Hewlett, J.D. and A.R. Hibbert. 1967. Factors affecting the response of small watersheds to precipitation in humid areas, p.275-290. In: W.E. Sopper and H.W. Lull (eds.) Proc. Int. Symp. On Forest Hydrology. Pergamonm Oxford.
Holechek, J.L, R.D. Pieper, and C.H. Herbel. 1998. Range management principles and practices. Prentice-Hall, Inc. 542 p. Upper Saddle River, N.J.

Lange, R.T. 1969. The piosphere: sheep track and dung patterns. J. Range Manage. 22:396-400.

Larsen, R.E. 1989. Water quality impacts of free ranging cattle in semi-arid environments. M.S. Thesis. Oregon State Univ., Corvallis, Ore.

Larsen, R.E. 1996. Survival and transport of fecal pathogens in grazed watersheds, p.59-71. In: M.R. George (ed) Livestock management in grazed watersheds. Univ. Calif. Div. Agric. and Nat. Resourc. Pub. 3381.

Miner, J.R., J.C. Buckhouse, and J.A. Moore. 1992. Will a water trough reduce the amount of time hay-fed livestock spend in the stream (and therefore improve water quality)? Rangelands. 14:35-38.

Mueggler, W.F. 1965. Cattle distribution on steep slopes. J. Range Manage. 18:255-257.

Pinheiro, J.C. and D.M. Bates. 2000. Theory and computational methods for LME models. In: Mixed Effects Model in S and S-Plus. pp. 57-96. Springer, N.Y.

Tate, K.W., E.R. Atwill, M.R. George, and N.K. McDougald. 2000a. Cryptosporidium parvum transport from cattle fecal deposits on California rangeland watersheds. J. Range Manage. 53:295-299.

Tate, K.W. E.R. Atwill, N.K. McDougald, M.R. George, and D. Witt. 2000b. A method for estimating cattle fecal loading on rangeland watersheds. J. Range Manage. 53:506-510.

Wagnon, K.A. 1963. Behavior of beef cows on a California range. California Ag. Expr. Stat. Bulletin 799. 58p. Berkeley, Calif.

Wagnon, K.A. 1968. Use of different classes of range land by cattle. California Ag. Expr. Stat. Bull. 838. 13 p. Berkeley, Calif. 